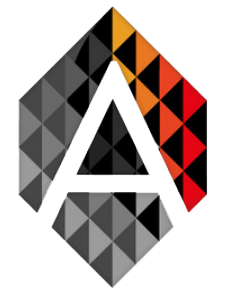

\title{
Intelligent Dolls and robots for the treatment of elderly people with dementia
}

\author{
SergioMárquez-Sánchez ${ }^{\mathrm{a}}$,SaraMora-Simon ${ }^{\mathrm{b}, \mathrm{c}}$,Jorge Herrera- \\ Santos $^{\mathrm{a}}$, Ana Olga Roncero ${ }^{\mathrm{d}}$ and Juan M. Corchado ${ }^{\mathrm{a}, \mathrm{d}, \mathrm{e}, \mathrm{f}}$ \\ ${ }^{a}$ Research group in Bioinformatics, Intelligent Computer Systems and Educational \\ Technology (BISITE), R\&B building, Calle Espejo s/n, 37008, Salamanca, Spain \\ b Department of Basic Psychology, Psychology and Behavioral Sciences Methodology, \\ Faculty of Psychology, University of Salamanca, Avda.de la Merced 109-131, 37005, \\ Salamanca, Spain \\ c Institute of Biomedical Research of Salamanca (IBSAL), Primary Care Research Unit of \\ Salamanca (APISAL), Avda. Portugal 83-2o, 37005, Salamanca, Spain \\ d Air Institute, IoT Digital Innovation Hub (Spain), 37188, Salamanca, Spain \\ e Department of Electronics, Information and Communication, Faculty of Engineering, \\ Osaka Institute of Technology, 535-8585 Osaka, Japan. \\ f Pusat Komputeran dan Informatik, Universiti Malaysia Kelantan, Karung Berkunci 36, \\ Pengkaan Chepa, 16100 Kota \\ smarquez@usal.es, s_mora@usal.es, jorgehsmp@usal.es, jm@ corchado.net
}

KEYWORD

Doll Therapy;

Robot Therapy;

Non- pharmaco-

logical thera-

py; Innovative therapy

\section{ABSTRACT}

Dolls and robots are effective and beneficial non-pharmacological therapies applied in different clinical settings. Doll therapy (DT), principally based on Bowlby's attachment theory, uses an empathy or lifelike baby doll to awaken caring behaviors in patients. Robot therapies $(R T)$ involve care robots that have a friendly attitude and appearance. They evoke different verbal, motor and emotional reactions in patients. Both DT and RT are person-centred therapies that provide patients with a realistic experience with the aim of improving their wellbeing. These therapies can be used in people suffering from different neurological, psychological and mental health disorders, such as Alzheimer's Disease, autism spectrum disorder, stress or depression. In this paper, the characteristics of both therapies, their benefits and the possibilities for innovation in the therapeutic field are presented.
Sergio Márquez-Sánchez, Sara Mora-Simon, Jorge Herrera-Santos, Ana Olga Roncero, and Juan M. Corchado Intelligent Dolls and robots for the treatment of elderly people with dementia
ADCAIJ: Advances in Distributed Computing and Artificial Intelligence Journal Regular Issue, Vol. 9 N. 1 (2020), 99-112 eISSN: 2255-2863 - https://adcaij.usal.es Ediciones Universidad de Salamanca - CC BY-NC-ND 


\section{Introduction}

Non-pharmacological therapies involve the use of versatile and low-cost tools in the treatment of different pathologies. They are referred to as non-drug administration, theoretically sustained, focal and replicable therapies, that can be administered to both the patient and the caregiver (Carballo-García et al., 2013; Olazaran et al., 2010). The use of different non-pharmacological therapies can lead to an improvement in cognitive and behavioral states, encouraging patients to perform daily activities. These positive effects reduce the need for restraint measures and improve quality of life of patients with dementia, which also contributes to the psychological wellbeing of their caregivers (Olazaran et al., 2010).

Sensory stimulation is one of the most applied non-pharmacological therapies. The term refers to a group of techniques that stimulate the senses in order to increase alertness, reduce agitation, and enhance the patients' quality of life (Strøm et al., 2016). Among them, doll and robot therapies offer beneficial and promising results (Bemelmans et al., 2012; Mitchell et al., 2016).

\section{Related Work}

\subsection{Doll therapy}

Even though there are many successful, non-pharmacological therapies, doll therapy (DT) is outstandingly effective. In this type of therapy, dolls are used in a careful and controlled way, to improve the wellbeing of people with dementia (Verity, 2006). It's a person-centered therapy that includes activities such as holding, talking to, feeding, cuddling or dressing the doll (Mitchell, 2014).

DT is based on Bowlby's attachment theory which states that human beings, since birth, need to develop a relationship with at least one caregiver for correct social and emotional development (Bowlby, 1969). Even through this theory only considers newborns, it's been extended to adolescents and adults - seeking attachment figures among their peers -, and to old people, who look for protection from their children (Bowlby, 2014; Ceberio, 2013). Likewise, this therapy is based on the person-centred care (Kitwood, 1997) and on transitional object theory (Winnicott, 1953), which argues that children cling to an object when separated from their caregiver.

However, in the last years, only several scientific studies have been conducted to examine the benefits of DT. In general, it has been proven that this therapy can reduce agitation and aggression, tendency to wander; increase wellbeing; increase interaction with staff and family members, reducing the need for psychotropic drugs (Mitchell, 2014). In the state of the art, there is a review of the literature on the therapeutic effects of DT in dementia, (Mitchell et al., 2016)). The review demonstrated that DT can reduce episodes of distress, anxiety, calling and wandering; encouraging the performance of daily activities, such as eating/drinking and sleeping. DT also gives patients more opportunities to communicate with others; and to fulfil their attachment, comfort, identity, inclusion and occupation needs (See Table 1).

Since DT became a therapeutic tool, different kinds of dolls have been used, nevertheless, two main types may be distinguished (Mitchell and Templeton, 2014). Firstly, empathy dolls are rag dolls made of cloth, and secondly, lifelike baby dolls which anatomically resemble human babies.

DT arose some ethical concerns, as the use of dolls could infantilise or demean elderly persons or persons suffering from dementia. Nonetheless, DT fulfils the principles of beneficence, non- maleficence and the concepts of respect for the autonomy and dignity of persons (Mitchell and Templeton, 2014; Ng et al., 2017).

Sergio Márquez-Sánchez, Sara Mora-Simon, Jorge Herrera-Santos, Ana Olga Roncero, and Juan M. Corchado Intelligent Dolls and robots for the treatment of elderly people with dementia
ADCAIJ: Advances in Distributed Computing and Artificial Intelligence Journal Regular Issue, Vol. 9 N. 1 (2020), 99-112 eISSN: 2255-2863 - https://adcaij.usal.es Ediciones Universidad de Salamanca - CC BY-NC-ND 


\subsection{Robot therapy}

Another successful non-pharmacological therapy is robot therapy (RT). Care robotics research and development have emerged in the last few decades (Goeldner et al., 2015).

Social robots can usually be classified into two types. The first one, are service type robots whose main functionality is to provide support in the performance of daily activities, mobility, household maintenance, and safety. The second type are companion robots that are designed to enhance the patients' health and psychological wellbeing through companionship. However, many robots can share the features of both types of robots (Broekens et al., 2009).

Table 1: Main effects of doll and robot therapies in patients with dementia

\begin{tabular}{|c|c|c|}
\hline Therapy & Author & Effect of the therapy \\
\hline \multirow{8}{*}{$\begin{array}{c}\text { Doll } \\
\text { therapy }\end{array}$} & \multirow{4}{*}{$\begin{array}{l}\text { Mitchell } \\
(2014)\end{array}$} & Reducted of BPSD: agitation, aggression, tendency to wander \\
\hline & & Increased of wellbeing \\
\hline & & $\begin{array}{l}\text { Improved of interaction between the patient, with family members } \\
\text { and staff }\end{array}$ \\
\hline & & Reduction in the use of psychotropic drugs \\
\hline & \multirow{4}{*}{$\begin{array}{l}\text { Mitchell et } \\
\text { al. (2016) }\end{array}$} & Reducted of BPSD: distress, anxiety, calling and wandering \\
\hline & & $\begin{array}{l}\text { Improvement in ADL: communicating, eating/ drinking, and sleep- } \\
\text { ing }\end{array}$ \\
\hline & & Facilitating opportunities to communicate with others \\
\hline & & $\begin{array}{l}\text { Fulfillment of attachment, comfort, identity, inclusion, and occupa- } \\
\text { tion needs }\end{array}$ \\
\hline \multirow{6}{*}{$\begin{array}{l}\text { Robot } \\
\text { therapy }\end{array}$} & \multirow{2}{*}{$\begin{array}{l}\text { Demange et } \\
\text { al. }(2018)\end{array}$} & Increase of positive affectivity \\
\hline & & Beneficial effect on psychological wellbeing \\
\hline & $\begin{array}{l}\text { Moyle et al. } \\
\text { (2013) }\end{array}$ & Improvement in the quality of life and pleasure \\
\hline & $\begin{array}{l}\text { Moyle et al. } \\
\quad(2017)\end{array}$ & Reduced motor activity \\
\hline & $\begin{array}{l}\text { Moyle et al. } \\
\text { (2018) }\end{array}$ & Increased engagement \\
\hline & $\begin{array}{l}\text { Valentí Soler } \\
\text { et al. (2015) }\end{array}$ & Reducted of BPSD: apathy \\
\hline
\end{tabular}

Note. BPSD: Behavioral and psychological symptoms of dementia. ADL: Activities of daily living.

Many social robots are used in the therapy, such as PARO, NAO or AIBO. But robots used in therapy usually have a friendly attitude and appearance, they are capable of demonstrating certain

Sergio Márquez-Sánchez, Sara Mora-Simon, Jorge Herrera-Santos, Ana Olga Roncero, and Juan M. Corchado Intelligent Dolls and robots for the treatment of elderly people with dementia
ADCAIJ: Advances in Distributed Computing and Artificial Intelligence Journal Regular Issue, Vol. 9 N. 1 (2020), 99-112 eISSN: 2255-2863 - https://adcaij.usal.es Ediciones Universidad de Salamanca - CC BY-NC-ND 
emotions and their main objective is that children and adults imitate these reactions and respond to them appropriately.

Some of these robots have a built-in automatic and personalized learning system that helps them estimate the patient's commitment and interest during their interactions (Feil-Seifer and Mataric', 2008). This arrangement is essential to achieve an optimal result, as this technology will be able to respond correctly to the patient's behavior, who should feel comfortable and safe during the session (Tapus et al., 2009). This is a complicated task even for therapists, who are unable to perfectly interpret the patient's movements, gestures and words.

The main studies analyzing the therapeutic effect of RT are focused on people who suffer from dementia (See Table 1). Interventions in which social robots are employed benefit positive affectivity and psychological wellbeing (Demange et al., 2018); decrease in apathy (Valentí Soler et al., 2015); increase in engagement (Moyle et al., 2017); motor activity reduced (Moyle et al., 2018); improving the quality of life and pleasure (Moyle et al., 2013). Robot interventions have many potential benefits, especially in managing behavioral symptoms and improving the quality of life of patients with dementia, however, additional research is required to study further positive effects of RT is needed (Bemelmans et al., 2012).

The long-term goal is not to create robots to replace human therapists, but to provide human therapists with key information that therapists could use to personalize the content of therapy and also to make interactions between robots and patients more engaging and natural. The robot could be used as a diagnostic tool which collects clinical data during therapy (Cabibihan et al., 2013; Can et al., 2016).

\section{The application of Doll and Robot Therapies}

Up until now, few scientific studies have analyzed the effectiveness of DT and RT in different populations. However, existing studies demonstrate the positive effects of these therapies, especially in the reduction of the behavioral and psychological symptoms of dementia (BPSD) (Cantarella et al., 2018; Mitchell and O’Donnell, 2013; Petersen et al., 2017).

\subsection{Doll and Robot therapies in Alzheimer's Disease and other dementias}

In the last few decades, the prevalence of chronic, cardiovascular and neurodegenerative diseases has increased due to higher life expectancy (Ferri et al., 2005).

Alzheimer's Disease (AD) is a neurodegenerative disease. In the last few years, there has been a considerable increase in the number of people suffering from $\mathrm{AD}$, which has led to many health, socio-economical, and political concerns. According to the World Health Organization, there were 52 million AD patients globally in 2015, where, approximately, 10 million new cases are diagnosed every year. Thus, it is estimated that this figure will reach 152 million in 2050 (OMS, 2019).

$\mathrm{AD}$ usually has an insidious beginning and causes progressive cognitive, functional and physical impairment as the disease develops (Valls-Pedret et al., 2010). A symptom that causes high distress in both $\mathrm{AD}$ or other dementia patients and the caregiver is BPSD. This symptom includes agitation, aberrant motor behavior, anxiety, elation, irritability, depression, apathy, disinhibition, delusions, hallucinations, and sleep or appetite changes and affects up to $90 \%$ of patients with dementia (Cerejeira et al., 2012).

Sergio Márquez-Sánchez, Sara Mora-Simon, Jorge Herrera-Santos, Ana Olga Roncero, and Juan M. Corchado Intelligent Dolls and robots for the treatment of elderly people with dementia
ADCAIJ: Advances in Distributed Computing and Artificial Intelligence Journal Regular Issue, Vol. 9 N. 1 (2020), 99-112 eISSN: 2255-2863 - https://adcaij.usal.es Ediciones Universidad de Salamanca - CC BY-NC-ND 
Psychosocial interventions in patients with moderate and severe stages of AD or other dementia are used to reduce BPSD (Cantarella et al., 2018). From a practical perspective, DT is one of the most used therapies for this purpose. It has been observed that DT causes a visible improvement in the BPSD of the patient by meeting their attachment needs, their agitation, apathy and depressive mood is reduced (Balzotti et al., 2019).

Counteracting those symptoms also helps reduce the distress experienced by the caregiver (Cantarella et al., 2018). DT is effective because it promotes the affective-relational dimension of attachment-caregiving in patients, creating and encouraging the maintenance of a relationship of attachment that results in less severe BPSD symptoms for at least two years (Pezzati et al., 2014) (See Table 2).

The beneficial effects of DT have also been reported by medical personnel (Braden and Gaspar, 2015) and caregivers, who observed that using a doll led to positive changes in the wellbeing of patients, making them feel calm, reduction in wandering, and improving intimate-care interactions (e.g. Bath) and improving speech (Mackenzie et al., 2006).

Furthermore, as a result of technological progress, new devices and robots are being developed to care for people who suffer from any physical and/or mental pathology and improve their quality of life (Goeldner et al., 2015). Among patients with dementia, PARO ( ) (Intelligent System Co., Kyoto, Japan) is widely used.

PARO is an autonomous baby seal robot that uses sensory stimulation based on animal therapy. It includes five sensors that allow it to respond to the user and the environment (Moyle et al., 2017). Several studies show that using PARO in people with dementia helps diminish BPSD as anxiety, stress (Petersen et al., 2017)agitation, depression, among other symptoms, as well as improving their quality of life, social interaction and attachment (Jøranson et al., 2015; Jøranson et al., 2016; Moyle et al., 2017), and night-time behavioral disturbances (Valentí Soler et al., 2015). Another care robot is NAO, a white humanoid robot with sensors for movement, touch, sonar, sound, and vision, it can talk and sing. It helps decrease apathy and stabilize general cognitive performance in people with advanced dementia (Valentí Soler et al., 2015). It has also been observed that using telepresence robots in people with dementia, such as Giraff, is associated with a more positive answer and fosters social connection with relatives and caregivers (Moyle et al., 2019a) (See Table 2).

Using robots in therapies improves psychological well-being in patients with major neurodegenerative disorders, promoting positive affectivity and reminiscence, and decreasing negative affectivity, especially in agitated patients (Demange et al., 2018). Choosing the correct robot is key to the success of a therapy. Sometimes, using robots can cause negative effects, such as an increase in irritability and the presence of hallucinations in people with dementia (Valentí Soler et al., 2015). Likewise, the effectiveness of RT may be affected by certain weak features of robots themselves or by the need of an occupational therapist assistance, as shown in a study that compared therapies using AIBO, a metal dog shaped robot that answers to spoken demands, with a toy dog intervention (Tamura et al., 2004).

Several studies that evaluate the effects of DT and RT in people with dementia show many positive effects. However, more studies are needed to further explore the benefits of DT and RT, which would build greater trust in using this therapy to treat patients (Moyle et al., 2019a; Moyle et al., 2019b).

Sergio Márquez-Sánchez, Sara Mora-Simon, Jorge Herrera-Santos, Ana Olga Roncero, and Juan M. Corchado

Intelligent Dolls and robots for the treatment of elderly people with dementia
ADCAIJ: Advances in Distributed Computing and Artificial Intelligence Journal Regular Issue, Vol. 9 N. 1 (2020), 99-112 eISSN: 2255-2863 - https://adcaij.usal.es Ediciones Universidad de Salamanca - CC BY-NC-ND 
Table 2: Beneficial effects of doll and robot therapies in patients with Alzheimer's Disease

\begin{tabular}{|c|c|c|c|}
\hline Therapy & Author & & Type and effect of the therapy \\
\hline \multirow{8}{*}{$\begin{array}{l}\text { Doll } \\
\text { therapy }\end{array}$} & $\begin{array}{l}\text { Balzotti et al. } \\
\qquad(2019)\end{array}$ & \multicolumn{2}{|c|}{ Reduction of BPSD: agitation, apathy and depressive mood } \\
\hline & \multirow{4}{*}{$\begin{array}{l}\text { Cantarella et } \\
\text { al. (2018) }\end{array}$} & \multicolumn{2}{|c|}{ Calming of BPSD } \\
\hline & & \multicolumn{2}{|c|}{ Relief for negative feelings } \\
\hline & & \multicolumn{2}{|c|}{ Meeting of attachment needs } \\
\hline & & \multicolumn{2}{|c|}{ Relief of caregiver's distress } \\
\hline & $\begin{array}{l}\text { Pezzati et al., } \\
2014\end{array}$ & \multicolumn{2}{|c|}{$\begin{array}{l}\text { Promotion and remaining of the affective-relational dimension } \\
\text { of attachment-caregiving }\end{array}$} \\
\hline & $\begin{array}{c}\text { Braden } \\
\text { and Gaspar } \\
(2015)\end{array}$ & \multicolumn{2}{|c|}{ Beneficial effects perceived by nurse and medical personnel } \\
\hline & $\begin{array}{l}\text { Mackenzie et } \\
\text { al. (2006) }\end{array}$ & \multicolumn{2}{|c|}{$\begin{array}{l}\text { Beneficial effect perceived by caregivers: positive effect on } \\
\text { wellbeing, reduction of BPSD and improvement in speech }\end{array}$} \\
\hline \multirow{11}{*}{$\begin{array}{l}\text { Robot } \\
\text { therapy }\end{array}$} & Demange et & \multicolumn{2}{|c|}{$\begin{array}{l}\text { Improvement of psychological wellbeing, positive affectivity and } \\
\text { reminiscence memories }\end{array}$} \\
\hline & & \multicolumn{2}{|c|}{ Reduction of negative affectivity (specially in agitated patients) } \\
\hline & $\begin{array}{l}\text { Jøranson et } \\
\text { al. (2015) }\end{array}$ & \multirow{3}{*}{ PARO } & \multirow[t]{2}{*}{ Reduction of BPSD: agitation and depression } \\
\hline & $\begin{array}{l}\text { Jøranson et } \\
\text { al. }(2016)\end{array}$ & & \\
\hline & $\begin{array}{l}\text { Moyle et al. } \\
\quad(2017)\end{array}$ & & $\begin{array}{l}\text { Improvement in quality of life, social interaction and } \\
\text { attachment }\end{array}$ \\
\hline & \multirow{2}{*}{$\begin{array}{l}\text { Moyle et al. } \\
\quad(2019)\end{array}$} & \multirow[b]{2}{*}{ Giraff } & Increase of positive answer \\
\hline & & & $\begin{array}{l}\text { Facilitation of social connection with relatives and } \\
\text { caregivers }\end{array}$ \\
\hline & $\begin{array}{l}\text { Petersen et } \\
\text { al. }(2017)\end{array}$ & PARO & Reduction of BPSD: anxiety and stress \\
\hline & $\begin{array}{l}\text { Valentí Soler } \\
\text { et al. (2015) }\end{array}$ & PARO & Reduction of night-time behavior disturbances \\
\hline & \multirow{2}{*}{$\begin{array}{l}\text { Valentí Soler } \\
\text { et al. (2015) }\end{array}$} & \multirow[b]{2}{*}{ NAO } & Reduction of apathy \\
\hline & & & $\begin{array}{l}\text { Stabilization of cognitive performance in advanced } \\
\text { dementia }\end{array}$ \\
\hline
\end{tabular}

Note. BPSD: Behavioral and psychological symptoms of dementia

Sergio Márquez-Sánchez, Sara Mora-Simon, Jorge Herrera-Santos, Ana Olga Roncero, and Juan M. Corchado Intelligent Dolls and robots for the treatment of elderly people with dementia
ADCAIJ: Advances in Distributed Computing and Artificial Intelligence Journal Regular Issue, Vol. 9 N. 1 (2020), 99-112 eISSN: 2255-2863 - https://adcaij.usal.es Ediciones Universidad de Salamanca - CC BY-NC-ND 


\subsection{Doll and robot therapies in Autism Spectrum Disorder}

inAutism Spectrum Disorder (ASD) is considered to be a neurodevelopmental disorder characterized by persistent deficits in communication and social interaction across multiple contexts and the presence of restricted, repetitive patterns of behavior, interests, or activities (APA, 2014). It has been observed that children with ASDtend to show high levels of negative affect, ambivalence and difficulties in social interaction that can affect, establish a secure attachment relationship with the parent (Martin et al., 2020).To the best of our knowledge, very few studies have been carried out on the use of a doll as a therapeutic or interventional tool in the study of levels of symbolic play (Marcu et al., 2009) or cradling bias (Pileggi et al., 2013; Pileggi et al., 2015). On the contrary, the application of robot technology is being widely studied in ASD children due to its potential capacity to create individualized, intensive, flexible and adaptative treatment approaches (Goodwin, 2008). Despite variability in results (Zheng et al., 2020), social and humanoid robots, such as NAO, have had positive outcomes

Table 3: The positive effects of doll and robot therapies on children and adolescents with Austism Spectrum Disorder

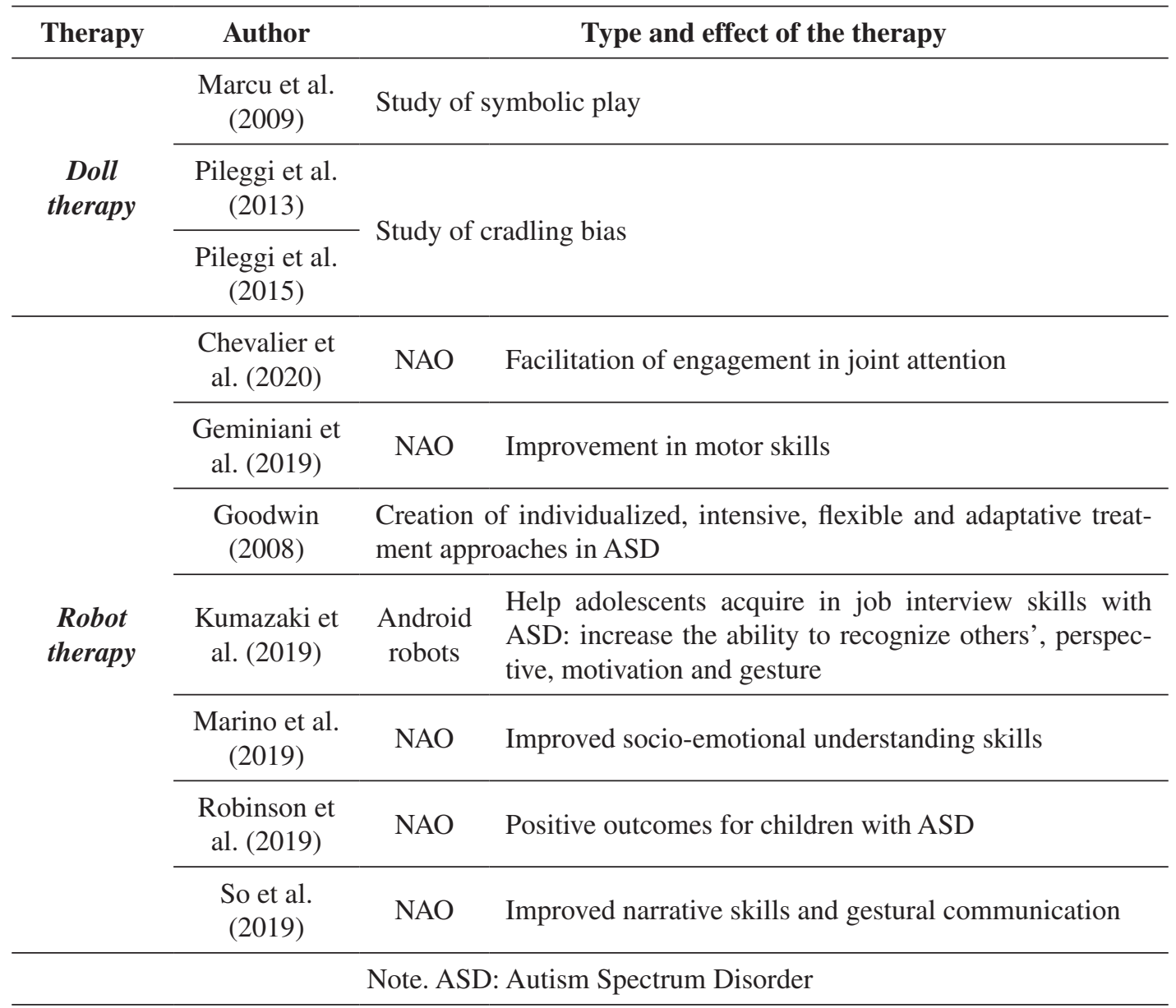

Sergio Márquez-Sánchez, Sara Mora-Simon, Jorge Herrera-Santos, Ana Olga Roncero, and Juan M. Corchado Intelligent Dolls and robots for the treatment of elderly people with dementia
ADCAIJ: Advances in Distributed Computing and Artificial Intelligence Journal Regular Issue, Vol. 9 N. 1 (2020), 99-112 eISSN: 2255-2863 - https://adcaij.usal.es Ediciones Universidad de Salamanca - CC BY-NC-ND 
in children with ASD (Robinson et al., 2019), because they facilitate engagement in joint attention, socio-emotional understanding skills (Marino et al., 2019), motor skills (Geminiani et al., 2019), or narrative skills and gestural communication (So et al., 2019). In case of ASD adolescents, android robots can help acquire job interview skills, leading to an increase in the recognition of other people's perspective, gesture and motivation (Kumazaki et al., 2019) (See Table 3).

Social and humanoid robots are well accepted by ASD children, as well as their parents and healthcare professionals (Dawe et al., 2019), suggesting that human-like robots are preferred over mechanic and pet robots (Kumazaki et al., 2017).

\subsection{Doll and robot therapies in other pathologies}

Doll therapy is widely used in dementia and ASD patients, as described previously. However, this therapy also has been applied to other fields, such as mental health. If depression comes along with dementia, DT can also help improve psychological wellbeing (McSweeney et al., 2012). In severe psychiatric adult patients, when traditional pharmacological treatment is not effective, DT can lead to clinical improvements, such as a reduction in verbal and physical aggression, screaming episodes and use of as-needed medication (Birnbaum et al., 2015). MMoreover, in children who have suffered from traumatic injury or congenital limb loss, DT applied in a hospital environment has many benefits since it helps reduce stress, understand the events, improve communication and it provide support at the different stages of limb loss (Billig and Weaver, 1996) (See Table 4).

Furthermore, RT and social robots may also benefit mental health (Fiske et al., 2019), as can be seen in Table 4. When applying RT in old people, it shows an impact in positive affectivity, increasing the level of happiness, quality of life, cognitive functioning; and decreases negative symptoms such as agitation, loneliness (Robinson et al., 2019). It seems that the positive physiological effect of RT may also lead to a fall in pulse rate, doses of pain medication and behavior medication (Petersen et al., 2017). Specifically, when using PARO in an elderly health service facility, mood, depression, and communication are improved; stress level decrease; and even, hormone levels improve. It has been demonstrated that the use of AIBO leads to a higher level of attachment and decreases loneliness (Bemelmans et al., 2012). In pediatric patients, PARO helps them to decrease pain and negative emotional anxiety. It can also be applied in joint patient-parent therapy, helping parents to reduce empathetic pain and negative emotions, and increasing the positive ones (Okita, 2013).

More studies are needed to fully analyze the role played by DT and RT in other clinical settings, and to assess their benefits. However, considering current studies they are highly promising tools and it is very possible that they have many positive effects in many clinical fields.

\section{Conclusions}

The benefits of using robots and dolls as non-pharmacological therapies are widely known, as they help reduce BPSD symptoms in patients with dementia, improving their quality of life. As a result of their positive effects, they also help reduce stress in caregivers. In children with ASD, this therapy fosters joint attention, socio- emotional understanding skills, as well as motor and linguistic skills; benefiting good mental health at different ages.

In a world where virtual interaction and robots made of cold materials are becoming increasingly popular, it is important to consider the possibilities that using electronic dolls would offer in a clinical

Sergio Márquez-Sánchez, Sara Mora-Simon, Jorge Herrera-Santos, Ana Olga Roncero, and Juan M. Corchado Intelligent Dolls and robots for the treatment of elderly people with dementia
ADCAIJ: Advances in Distributed Computing and Artificial Intelligence Journal Regular Issue, Vol. 9 N. 1 (2020), 99-112 eISSN: 2255-2863 - https://adcaij.usal.es Ediciones Universidad de Salamanca - CC BY-NC-ND 
Table 4: Beneficial effects of doll and robot therapies in different pathologies

\begin{tabular}{|c|c|c|c|c|}
\hline Therapy & Author & Pathology & & Type and effect of the therapy \\
\hline \multirow{4}{*}{$\begin{array}{l}\text { Doll } \\
\text { therapy }\end{array}$} & \multirow{2}{*}{$\begin{array}{c}\text { Billig and } \\
\text { Weaver (1996) }\end{array}$} & \multirow{2}{*}{$\begin{array}{l}\text { Limb loss in } \\
\text { children }\end{array}$} & \multicolumn{2}{|c|}{ Reduction of stress } \\
\hline & & & \multicolumn{2}{|c|}{$\begin{array}{l}\text { Improvement of understanding of the events, com- } \\
\text { munications and helping in stages of limb loss }\end{array}$} \\
\hline & $\begin{array}{l}\text { Birnbaum et al. } \\
\text { (2015) }\end{array}$ & $\begin{array}{l}\text { Psychiatric } \\
\text { disorder in } \\
\text { adults }\end{array}$ & \multicolumn{2}{|c|}{$\begin{array}{l}\text { Clinical improvements in reduction in verbal and } \\
\text { physical aggression, screaming episodes and use of } \\
\text { medication }\end{array}$} \\
\hline & $\begin{array}{l}\text { McSweeney et } \\
\text { al. (2012) }\end{array}$ & $\begin{array}{c}\text { Depression } \\
\text { with dementia }\end{array}$ & \multicolumn{2}{|c|}{ Improvement of psychological wellbeing } \\
\hline \multirow{11}{*}{$\begin{array}{l}\text { Robot } \\
\text { therapy }\end{array}$} & \multirow{5}{*}{$\begin{array}{l}\text { Bemelmans et } \\
\text { al. (2012) }\end{array}$} & \multirow{5}{*}{ Aging } & \multirow{3}{*}{ PARO } & Improved mood and communication \\
\hline & & & & Decrease in depressive states \\
\hline & & & & Improved of hormone levels \\
\hline & & & \multirow{2}{*}{ AIBO } & Increased attachment \\
\hline & & & & Decreased sense of loneliness \\
\hline & \multirow{3}{*}{ Okita (2013) } & \multirow{3}{*}{$\begin{array}{l}\text { Pediatric } \\
\text { patients }\end{array}$} & \multirow{3}{*}{ PARO } & $\begin{array}{l}\text { Decrease in pain and negative emotional } \\
\text { anxiety }\end{array}$ \\
\hline & & & & Reducted of empathetic pain \\
\hline & & & & $\begin{array}{l}\text { Decrease in negative and increase in pos- } \\
\text { itive emotions in parents }\end{array}$ \\
\hline & $\begin{array}{l}\text { Petersen et al. } \\
\qquad(2017)\end{array}$ & Aging & \multicolumn{2}{|c|}{$\begin{array}{l}\text { Positive physiological effect: fall in pulse rate and } \\
\text { in pain medication and behavior medication does }\end{array}$} \\
\hline & \multirow{2}{*}{$\begin{array}{l}\text { Robinson et al. } \\
\qquad \text { (2019) }\end{array}$} & \multirow{2}{*}{ Aging } & \multicolumn{2}{|c|}{$\begin{array}{l}\text { Improved in positive affectivity, expressions of hap- } \\
\text { piness, quality of life and cognitive functioning }\end{array}$} \\
\hline & & & \multicolumn{2}{|c|}{$\begin{array}{l}\text { Decrease in negative symptoms, agitation and lone- } \\
\text { liness }\end{array}$} \\
\hline
\end{tabular}

environment. Robot dolls could help patients with AD, dementia, ASD, trauma, as well as other mental health disorders and psychological problems, such as stress, anxiety and pain.

Considering the analysis carried out in this work, we intend to create an application where several elements can be interconnected and whose main element is an electronic doll. Sensors and components will be integrated in such a way that they will come unnoticed by users. In addition, the use of technologies for wearable sensorization, mobile technology or electronic textiles, would bring great innovative value to the project.

Sergio Márquez-Sánchez, Sara Mora-Simon, Jorge Herrera-Santos, Ana Olga Roncero, and Juan M. Corchado

Intelligent Dolls and robots for the treatment of elderly people with dementia
ADCAIJ: Advances in Distributed Computing and Artificial Intelligence Journal Regular Issue, Vol. 9 N. 1 (2020), 99-112 eISSN: 2255-2863 - https://adcaij.usal.es Ediciones Universidad de Salamanca - CC BY-NC-ND 
The system integrated in the doll could cover a wide range of therapeutic roles. If the doll had an adaptable system applied which, depending on, that would provide it with information on how to interact with the patient on the basis of the real conditions and reactions of the user in the environment. It could also provide a great amount of information and behavior patterns to the therapists, health professionals, caregivers or even the automatic learning system.

Robotics invite us to overcome new challenges and find new solutions, such as an innovative electronic doll model. Nevertheless, more studies are needed to prove their therapeutic and clinical benefits.

\section{References}

Association, A. P., 2014. DSM-5. Manual diagnóstico y estadístico de los trastornos mentales. Editorial Médica Panamericana.

Balzotti, A., Filograsso, M., Altamura, C., Fairfield, B., Bellomo, A., Daddato, F., Vacca, R. A., and Altamura, M., 2019. Comparison of the efficacy of gesture-verbal treatment and doll therapy for managing neuropsychiatric symptoms in older patients with dementia. International Journal of Geriatric Psychiatry, 34(9):1308-1315. doi:10.1002/gps.4961.

Bemelmans, R., Gelderblom, G. J., Jonker, P., and de Witte, L., 2012. Socially assistive robots in elderly care: a systematic review into effects and effectiveness. Journal of the American Medical Directors Association, 13(2):114-120 e1. doi:10.1016/j.jamda.2010.10.002.

Billig, T. and Weaver, K., 1996. Individualized doll therapy with children experiencing limb loss. Orthopedic Nursing, 15(6):50-5.

Birnbaum, S., Hanchuk, H., and Nelson, M., 2015. Therapeutic doll play in the treatment of a severely impaired psychiatric inpatient: dramatic clinical improvements with a nontraditional nursing intervention. Journal of Psychosocial Nursing and Mental Health Services, 53(5):22-7. doi:10.3928/0279369520150424-33.

Bowlby, J., 1969. Attachement and Loss: Attachment, volume I. Hogarth, Londres.

Bowlby, J., 2014. Vínculos afectivos: formación, desarrollo y pérdida. Morata, Madrid, 6a edition.

Braden, B. A. and Gaspar, P. M., 2015. Implementation of a baby doll therapy protocol for people with dementia: Innovative practice. Dementia (London), 14(5):696-706. doi:10.1177/1471301214561532.

Broekens, J., Heerink, M., and Rosendal, H., 2009. Assistive social robots in elderly care: a review.

Gerontechnology, 8(2):94-103.

Cabibihan, J.-J., Javed, H., Ang, M., and Aljunied, S. M., 2013. Why robots? A survey on the roles and benefits of social robots in the therapy of children with autism. International journal of social robotics, 5(4):593-618.

Can, W. S. R., Seibt, S. D. J. et al., 2016. Social robotics, elderly care, and human dignity: A recognitiontheoretical approach. What social robots can and should do: Proceedings of robophilosophy 2016/ TRANSOR 2016, 290.

Cantarella, A., Borella, E., Faggian, S., Navuzzi, A., and De Beni, R., 2018. Using dolls for therapeutic purposes: A study on nursing home residents with severe dementia. International Journal of Geriatric Psychiatry, 33(7):915-925. doi:10.1002/gps.4872.

Sergio Márquez-Sánchez, Sara Mora-Simon, Jorge Herrera-Santos, Ana Olga Roncero, and Juan M. Corchado

Intelligent Dolls and robots for the treatment of elderly people with dementia
ADCAIJ: Advances in Distributed Computing and Artificial Intelligence Journal Regular Issue, Vol. 9 N. 1 (2020), 99-112 eISSN: 2255-2863 - https://adcaij.usal.es Ediciones Universidad de Salamanca - CC BY-NC-ND 
Carballo-García, V., Arroyo-Arroyo, M., Portero-Díaz, M., and Ruiz-Sánchez de León, J., 2013. Effects of non-pharmacological therapy on normal ageing and on cognitive decline: reflections on treatment objectives. Neurología, 28(3):160-168.

Ceberio, M., 2013. El cielo puede esperar. La cuarta edad: ser anciano en el siglo XXI. Morata, Madrid.

Cerejeira, J., Lagarto, L., and Mukaetova-Ladinska, E. B., 2012. Behavioral and psychological symptoms of dementia. Frontiers in Neurology, 3:73. doi:10.3389/fneur.2012.00073.

Dawe, J., Sutherland, C., Barco, A., and Broadbent, E., 2019. Can social robots help children in healthcare contexts? A scoping review. BMJ Paediatrics Open, 3(1):e000371. doi:10.1136/bmjpo-2018-000371.

Demange, M., Lenoir, H., Pino, M., Cantegreil-Kallen, I., Rigaud, A. S., and Cristancho-Lacroix, V., 2018. Improving well-being in patients with major neurodegenerative disorders: differential efficacy of brief social robot-based intervention for 3 neuropsychiatric profiles. Clinical Interventions in Aging, 13:1303-1311. doi:10.2147/cia.s152561.

Feil-Seifer, D. and Mataric', M., 2008. Robot-assisted therapy for children with autism spectrum disorders. pages 49-52.

Ferri, C. P., Prince, M., Brayne, C., Brodaty, H., Fratiglioni, L., Ganguli, M., Hall, K., Hasegawa, K., Hendrie, H., Huang, Y., Jorm, A., Mathers, C., Menezes, P. R., Rimmer, E., and Scazufca, M., 2005. Global prevalence of dementia: a Delphi consensus study. Lancet, 366(9503):2112-7. doi:10.1016/ s0140-6736(05)67889-0.

Fiske, A., Henningsen, P., and Buyx, A., 2019. Your Robot Therapist Will See You Now: Ethical Implications of Embodied Artificial Intelligence in Psychiatry, Psychology, and Psychotherapy. Journal of Medical Internet Research, 21(5):e13216. doi:10.2196/13216.

Geminiani, A., Santos, L., Casellato, C., Farabbi, A., Farella, N., Santos-Victor, J., Olivieri, I., and Pedrocchi, A., 2019. Design and validation of two embodied mirroring setups for interactive games with autistic children using the NAO humanoid robot. Conference Proceedings. IEEE Engineering in Medicine and Biological Society, 2019:1641-1644. doi:10.1109/embc.2019.8857576.

Goeldner, M., Herstatt, C., and Tietze, F., 2015. The emergence of care robotics - A patent and publication analysis. Technological Forecasting Social Change, 92:115-131.

Goodwin, M., 2008. Enhancing and accelerating the pace of autism research and treatment. Focus on Autism and Other Developmental Disabilities, 23(2):125-128.

Jøranson, N., Pedersen, I., Rokstad, A. M., and Ihlebaek, C., 2016. Change in quality of life in older people with dementia participating in Paro-activity: a cluster-randomized controlled trial. Journal of advanced nursing, 72(12):3020-3033. doi:10.1111/jan.13076.

Jøranson, N., Pedersen, I., Rokstad, A. M., and Ihlebæk, C., 2015. Effects on Symptoms of Agitation and Depression in Persons With Dementia Participating in Robot-Assisted Activity: A Cluster-Randomized Controlled Trial. Journal of the American Medical Directors Association, 16(10):867-73. doi:10.1016/j. jamda.2015.05.002.

Kitwood, T., 1997. Dementia Reconsidered: The Person Comes First (Rethinking Ageing). Open University Press, Buckingham.

Kumazaki, H., Muramatsu, T., Yoshikawa, Y., Matsumoto, Y., Ishiguro, H., Mimura, M., and Kikuchi, M., 2019. Role-Play-Based Guidance for Job Interviews Using an Android Robot for Individuals With Autism Spectrum Disorders. Frontiers in Psychiatry, 10:239. doi:10.3389/fpsyt.2019.00239.

Kumazaki, H., Warren, Z., Muramatsu, T., Yoshikawa, Y., Matsumoto, Y., Miyao, M., Nakano, M., Mizushima, S., Wakita, Y., Ishiguro, H., Mimura, M., Minabe, Y., and Kikuchi, M., 2017. A pilot study

Sergio Márquez-Sánchez, Sara Mora-Simon, Jorge Herrera-Santos, Ana Olga Roncero, and Juan M. Corchado

Intelligent Dolls and robots for the treatment of elderly people with dementia
ADCAIJ: Advances in Distributed Computing and Artificial Intelligence Journal Regular Issue, Vol. 9 N. 1 (2020), 99-112 eISSN: 2255-2863 - https://adcaij.usal.es Ediciones Universidad de Salamanca - CC BY-NC-ND 
for robot appearance preferences among high-functioning individuals with autism spectrum disorder: Implications for therapeutic use. PLoS One, 12(10):e0186581. doi:10.1371/journal.pone.0186581.

Mackenzie, L., James, I. A., Morse, R., Mukaetova-Ladinska, E., and Reichelt, F. K., 2006. A pilot study on the use of dolls for people with dementia. Age and Ageing, 35(4):441-4. doi:10.1093/ageing/ afl007.

Marcu, I., Oppenheim, D., Koren-Karie, N., Dolev, S., and Yirmiya, N., 2009. Attachment and symbolic play in preschoolers with autism spectrum disorders. Journal of Autism and Developmental Disorders, 39(9):1321-8. doi:10.1007/s10803-009-0747-y.

Marino, F., Chila, P., Sfrazzetto, S. T., Carrozza, C., Crimi, I., Failla, C., Busa, M., Bernava, G., Tartarisco, G., Vagni, D., Ruta, L., and Pioggia, G., 2019. Outcomes of a Robot-Assisted Social-Emotional Understanding Intervention for Young Children with Autism Spectrum Disorders. Journal of Autism and Developmental Disorders. ISSN 1573-3432 (Electronic) 0162-3257 (Linking). doi:10.1007/ s10803-019-03953-x.

Martin, K. B., Haltigan, J. D., Ekas, N., Prince, E. B., and Messinger, D. S., 2020. Attachment security differs by later autism spectrum disorder: A prospective study. Developmental Science, page e12953. ISSN 1467-7687 (Electronic) 1363-755X (Linking). doi:10.1111/desc.12953.

McSweeney, K., Jeffreys, A., Griffith, J., Plakiotis, C., Kharsas, R., and O'Connor, D. W., 2012. Specialist mental health consultation for depression in Australian aged care residents with dementia: a cluster randomized trial. International Journal of Geriatric Psychiatry, 27(11):1163-71. doi:10.1002/ gps.3762.

Mitchell, G., 2014. Use of doll therapy for people with dementia: an overview. Nursing Older People, 26(4):24-6. doi:10.7748/nop2014.04.26.4.24.e568.

Mitchell, G., McCormack, B., and McCance, T., 2016. Therapeutic use of dolls for people living with dementia: A critical review of the literature. Dementia (London), 15(5):976-1001. doi:10.1177/1471301214548522. Mitchell, G. and O’Donnell, H., 2013. The therapeutic use of doll therapy in dementia. British Journal of

Nursing, 22(6):329-34. doi:10.12968/bjon.2013.22.6.329.

Mitchell, G. and Templeton, M., 2014. Ethical considerations of doll therapy for people with dementia. Nursing Ethics, 21(6):720-30. doi:10.1177/0969733013518447.

Moyle, W., Cooke, M., Beattie, E., Jones, C., Klein, B., Cook, G., and Gray, C., 2013. Exploring the effect of companion robots on emotional expression in older adults with dementia: a pilot randomized controlled trial. Journal of Gerontological Nursing, 39(5):46-53.

Moyle, W., Jones, C., Dwan, T., Ownsworth, T., and Sung, B., 2019a. Using telepresence for social connection: views of older people with dementia, families, and health professionals from a mixed methods pilot study. Aging Mental Health, 23(12):1643-1650. doi:10.1080/13607863.2018.1509297.

Moyle, W., Jones, C., Murfield, J., Thalib, L., Beattie, E., Shum, D., O’Dwyer, S., Mervin, M. C., and Draper, B., 2018. Effect of a robotic seal on the motor activity and sleep patterns of older people with dementia, as measured by wearable technology: A cluster-randomised controlled trial. Maturitas, 110:10-17.

Moyle, W., Jones, C. J., Murfield, J. E., Thalib, L., Beattie, E. R. A., Shum, D. K. H., O’Dwyer, S. T., Mervin, M. C., and Draper, B. M., 2017. Use of a Robotic Seal as a Therapeutic Tool to Improve Dementia Symptoms: A Cluster-Randomized Controlled Trial. Journal of the American Medical Directors Association, 18(9):766-773. doi:10.1016/j.jamda.2017.03.018.

Sergio Márquez-Sánchez, Sara Mora-Simon, Jorge Herrera-Santos, Ana Olga Roncero, and Juan M. Corchado Intelligent Dolls and robots for the treatment of elderly people with dementia
ADCAIJ: Advances in Distributed Computing and Artificial Intelligence Journal Regular Issue, Vol. 9 N. 1 (2020), 99-112 eISSN: 2255-2863 - https://adcaij.usal.es Ediciones Universidad de Salamanca - CC BY-NC-ND 
Moyle, W., Murfield, J., Jones, C., Beattie, E., Draper, B., and Ownsworth, T., 2019b. Can lifelike baby dolls reduce symptoms of anxiety, agitation, or aggression for people with dementia in long-term care? Findings from a pilot randomised controlled trial. Aging Mental Health, 23(10):1442-1450. ISSN 1360-7863. doi:10.1080/13607863.2018.1498447.

Ng, Q. X., Ho, C. Y., Koh, S. S., Tan, W. C., and Chan, H. W., 2017. Doll therapy for dementia sufferers: A systematic review. Complementary Therapies in Clinical Practice, 26:42-46. doi:10.1016/j. ctcp.2016.11. 007.

Okita, S. Y., 2013. Self-other's perspective taking: the use of therapeutic robot companions as social agents for reducing pain and anxiety in pediatric patients. Cyberpsychology, Behavior and Social networking, 16(6):436-41. doi:10.1089/cyber.2012.0513.

Olazaran, J., Reisberg, B., Clare, L., Cruz, I., Pena-Casanova, J., Del Ser, T., Woods, B., Beck, C., Auer, S., Lai, C., Spector, A., Fazio, S., Bond, J., Kivipelto, M., Brodaty, H., Rojo, J. M., Collins, H., Teri, L., Mittelman, M., Orrell, M., Feldman, H. H., and Muniz, R., 2010. Nonpharmacological therapies in Alzheimer's disease: a systematic review of efficacy. Dementia and Geriatric Cognitive Disorders, 30(2):161-78. doi:10.1159/000316119.

Organization, W. H., 2019. Dementia.

Petersen, S., Houston, S., Qin, H., Tague, C., and Studley, J., 2017. The Utilization of Robotic Pets in Dementia Care. Journal of Alzheimer's Disease, 55(2):569-574. doi:10.3233/jad-160703.

Pezzati, R., Molteni, V., Bani, M., Settanta, C., Di Maggio, M. G., Villa, I., Poletti, B., and Ardito, R. B., 2014. Can Doll therapy preserve or promote attachment in people with cognitive, behavioral, and emotional problems? A pilot study in institutionalized patients with dementia. Frontiers in Psychology, 5:342. doi:10.3389/fpsyg.2014.00342.

Pileggi, L. A., Malcolm-Smith, S., Hoogenhout, M., Thomas, K. G., and Solms, M., 2013. Cradling bias is absent in children with autism spectrum disorders. Journal of Child and Adolescent Mental Health, 25(1):55-60. doi:10.2989/17280583.2013.767262.

Pileggi, L. A., Malcolm-Smith, S., and Solms, M., 2015. Investigating the role of social-affective attachment processes in cradling bias: the absence of cradling bias in children with Autism Spectrum Disorders.

Laterality, 20(2):154-70. doi:10.1080/1357650x.2014.948449.

Robinson, N. L., Cottier, T. V., and Kavanagh, D. J., 2019. Psychosocial Health Interventions by Social Robots: Systematic Review of Randomized Controlled Trials. Journal of Medical Internet Research, 21(5):e13203. doi:10.2196/13203.

So, W. C., Cheng, C. H., Lam, W. Y., Wong, T., Law, W. W., Huang, Y., Ng, K. C., Tung, H. C., and Wong, W., 2019. Robot-based play-drama intervention may improve the narrative abilities of Chinese-speaking preschoolers with autism spectrum disorder. Research in Developmental Disabilities, 95:103515. doi: 10.1016/j.ridd.2019.103515.

Strøm, B. S., Ytrehus, S., and Grov, E. K., 2016. Sensory stimulation for persons with dementia: a review of the literature. Journal of Clinical Nursing, 25(13-14):1805-34. doi:10.1111/jocn.13169.

Tamura, T., Yonemitsu, S., Itoh, A., Oikawa, D., Kawakami, A., Higashi, Y., Fujimooto, T., and Nakajima, K., 2004. Is an entertainment robot useful in the care of elderly people with severe dementia? The Journals of Gerontology. Series A, Biological Sciences and Medical Sciences, 59(1):83-5. doi:10.1093/gerona/59.1.m83.

Tapus, A., Tapus, C., and Mataric, M. J., 2009. The use of socially assistive robots in the design of intelligent cognitive therapies for people with dementia. pages 924-929.

Sergio Márquez-Sánchez, Sara Mora-Simon, Jorge Herrera-Santos, Ana Olga Roncero, and Juan M. Corchado

Intelligent Dolls and robots for the treatment of elderly people with dementia
ADCAIJ: Advances in Distributed Computing and Artificial Intelligence Journal Regular Issue, Vol. 9 N. 1 (2020), 99-112 eISSN: 2255-2863 - https://adcaij.usal.es Ediciones Universidad de Salamanca - CC BY-NC-ND 
Valentí Soler, M., Agüera-Ortiz, L., Olazarán Rodríguez, J., Mendoza Rebolledo, C., Pérez Muñoz, A., Rodríguez Pérez, I., Osa Ruiz, E., Barrios Sánchez, A., Herrero Cano, V., Carrasco Chillón, L., Felipe Ruiz, S., López Alvarez, J., León Salas, B., Cañas Plaza, J. M., Martín Rico, F., Abella Dago, G., and Martínez Martín, P., 2015. Social robots in advanced dementia. Frontiers in Aging Neuroscience, 7:133. doi:10.3389/fnagi.2015.00133.

Valls-Pedret, C., Molinuevo, J. L., and Rami, L., 2010. Diagnóstico precoz de la enfermedad de Alzheimer: fase prodrómica y preclínica. Revista de Neurología, 51(8):471-80.

Verity, J., 2006. Dolls in dementia care: bridging the divide. Journal of Dementia Care, 14(1):25-27. Winnicott, W., 1953. Traditional objects and transitional phenomena: a study of the first not-me possession. The International Journal of Psychoanalysis, 34. 